\title{
DEN BRØLENDE TAVSHED
}

\section{Kjeld Schmidt}

Den fascistiske stat er en moderne stat. Den etatistiske kontrarevolution er en moderne kontrarevolution.

Når borgerskabets herredømme trues, reagerer det totalitært. Den klasse, der var bærer af liberalismen, er også bærer af antiliberalismen, hvilket ikke er så underligt: begge ideologier tjener til forsvar af de kapitalistiske produktionsforhold.

Omend den revolutionære bevægelse i Danmark ikke udgør nogen akut trusel mod borgerskabets herredømme (det, Baunsgård i Folketinget under forespørgselsdebatten om den tiltagende brug af politistatsmetoder kaldte "den lovlige samfundsorden", som om det var Gud og ikke Staten selv, der havde lavet lovene), så har denne klasses betalte lænkehunde dog vejret krudtrøg; de fascistoide træk bliver subjektivt erkendelige.

Lænkehundenes terminologi har således ændret sig med situationen; da den revolutionære bevægelse kun var et tilløb til en sådan, tav man; senere talte man om bøller og gadedrengestreger; senere igen begyndte man at tale om 'små minoritetsgrupper' (Hartling). Når ordet minoritet bruges pejorativt, ved vi, hvad klokken er slået. Sammen med dette ord kommer også lugten af blod.

Men når det nu lykkes disse "små minoritetsgrupper" at afsløre, at der er noget, der forsvares med alle til rådighed stående midler (og som det før er sket $i$ dette lands historie: også med grundlovsstridige midler), når det lykkes dem at punktere "den lovlige samfundsorden's i forvejen ikke alt for solide legimitet, - så er det på tide at slå til; cf., hvad Mussolini-apologeten Ole Bjørn Kraft sagde på det Konservative Folkepartis landsmøde (29.-30.11):

"Man kalder det drengestreger, men de, der står bag, sigter mod et bestemt mål. De skaber en følelse af usikkerhed og uro. Anslag mod statens autoritet skal mødes med fasthed."

Det er på baggrund af denne etatistiske kontrarevolution, at apellen fra lænkehundene til det store tavse flertal skal forstås.

Det er det store tavse flertals fortjeneste, at det ikke blander sig i politik.

"Det store flertal hører til de stille, der passer arbejdsplads og aftenskolearbejde." (Poul Møller på samme landsmøde).

Deres passivitet er deres dyd. Mens den tidlige liberalisme appellerede til "offentligheden", d.v.s. en kritisk opinion, appellerer de moderne lænkehunde til de stummes uudtalte og derfor statsbærende meninger. Mens det tidligere var en forudsætning for demokratiet, parlamentarismen og retssamfundet" (Poul Møller), at der var en offentlighed, er det nu en forudsætning, at der ikke er en offentlighed. Afpolitiseringen og privatiseringen er en forudsætning for senkapitalismens skrøbelige stabilitet. 


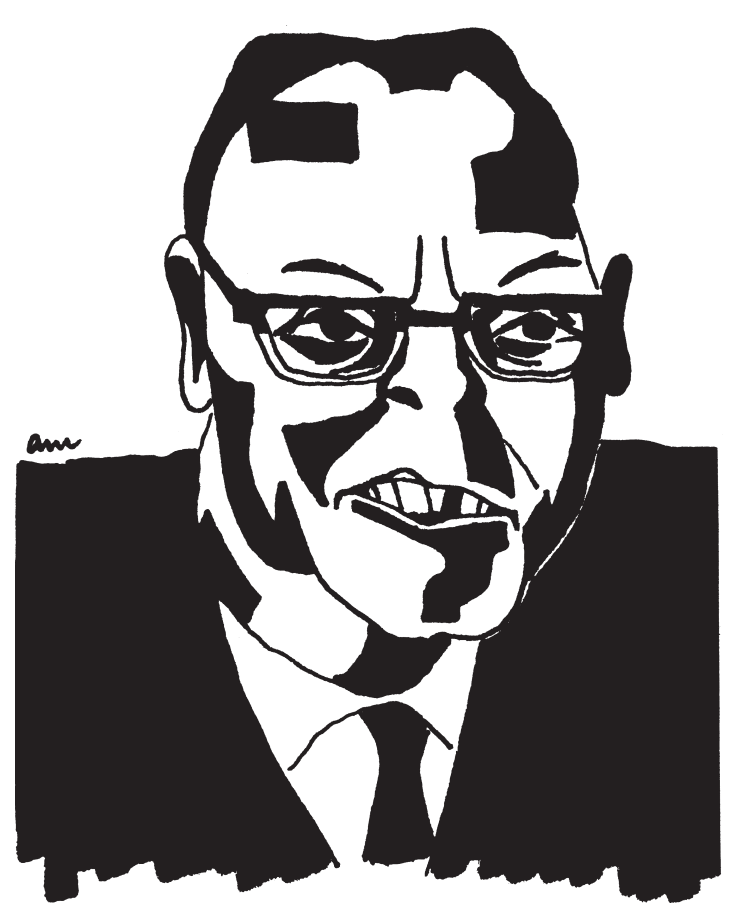

Det store tavse flertal er en apolitisk og uorganiseret masse; at tillægge en sådan ansamling af individer bestemte politiske meninger er absurd. Der er tale om en regulær solipsisme, d.v.s. at man underforstår, "at det indre liv er noget bestemt og klart udformet, også før det kommer til udtryk. Men dette er stort set uholdbart. Det indre liv er oftest flygtigt og ubestemt .... Dersom vi lever et såkaldt rigt indre liv, så er det ikke bare skjult for andre, men måske heller ikke noget at vise frem, dersom vi prøvede det." (Dag Østerberg: Forståelsesformer, Oslo-66 p. 73).

Men når de af de statsbærende partier - fra det Socialistiske til det Konservative Folkeparti - så foragtede aktivister formår at rejse et politisk spørgsmål, med andre ord at skabe en offentlighed, tendensielt at politisere det store, tavse flertal så er det på tide for de statsbærende partier at slå fra sig: ved (over for medlemmerne af det store tavse flertal) at udgive sig for at repræsentere dette tavse flertals illusoriske totalitet: det gælder om at få enhver til at tro, at de andre mener som Poul Møller og de andre lænkehunde. Akkurat som det lykkedes fascisterne at fascinere enhver tysker til at tro, at han - ved at være antisemit handlede som enhver anden.

Men $i$ et samfund, hvor det er en dyd at være politisk passiv og indifferent, kan man ikke tage de således dydige til indtægt for en bestemt politik: det er at ville afpolitisere og politisere på én gang. Man vil på én gang dæmme op for den revolutionære bevægelses politisering af det store tavse flertal - og samtidig påberåbe sig dette flertals ikke eksisterende politiske meninger. Dette, de statsbærende partiers dilemma, er den revolutionære bevægelses håb.

Hos lønarbejderne beror senkapitalismens eneste legitimitet på, at den sikrer en støt stigende levefod og fred til at fordøje denne støt stigende levefod. Kort sagt: senkapitalismen er kun legitim, forsåvidt som den skaffer madro.

Senkapitalismen besidder ikke hos denne klasse en sådan legitimitet, at den ville droppe madroen og lade sig politisere til forsvar for den bestående orden; og der eksisterer ikke længere et talstærkt småborgerskab, der er $i$ færd med at blive likvideret som klasse, og som derfor (da de vil forsøge at restaurere det tabte) kan sættes ind til forsvar for den bestående orden. Det vil sige, at borgerskabets sidste skanse: den totalitære stat, ikke længere lader sig rejse: borgerskabet mangler barrikademateriale. Fascismen er pr. definition en massebevægelse, og en totalitær stat, der ikke bygger på en massebevægelse - er en uting.

Det vil sige, at fascismens epoke er fortid. Men det, der gjorde den fascistiske stat til en moderne stat, det er ikke racismen, irrationalismen eller antiliberalismen (i bred forstand), men korporativismen, klassesamarbejdet - og det er ikke fortid cf. Selskabet for Samfundsdebat.

Summa summarum: lænkehundene kan benytte sig af politistatsmetoder; men $i$ den udstrækning det bliver nødvendigt at politisere for at forsvare borgerskabets herredømme, i den udstrækning er borgerskabets herredømme en saga blott.

Borgerskabet og dets lænkehunde er fanget $i$ historiens store rottefælde. 